\title{
Reshaping the policy debate on the implications of COVID-19 for global supply chains
}

\author{
Sébastien Miroudot \\ Organisation for Economic Co-operation and \\ Development, 2 rue André-Pascal, \\ 75775 Paris Cedex 16, France \\ Correspondence: \\ $S$ Miroudot, Organisation for Economic Co- \\ operation and Development, 2 rue André- \\ Pascal, 75775 Paris Cedex 16, France \\ e-mail: sebastien.miroudot@oecd.org
}

\begin{abstract}
Disruptions in global supply chains in the context of the COVID-19 pandemic have re-opened the debate on the vulnerabilities associated with production in complex international production networks. To build resilience in supply chains, several authors suggest making them shorter, more domestic, and more diversified. This paper argues that before redesigning global supply chains, one needs to identify the concrete issues faced by firms during the crisis and the policies that can solve them. It highlights that the solutions that have been proposed tend to be disconnected from the conclusions of the supply chain literature, where reshoring does not lead to resilience, and could further benefit from the insights of international business and global value chain scholars. Lastly, the paper discusses the policies that can build resilience at the firm and global levels and the narrative that could replace the current one to reshape the debate on the policy implications of COVID-19 for global supply chains. Journal of International Business Policy (2020) 3, 430-442. https://doi.org/ | 0.1 057/s422/4-020-00074-6
\end{abstract}

Keywords: COVID-19; international business; global value chains; risk management; resilience

With COVID-19, the debate has re-emerged on the vulnerabilities of an interconnected world where goods are produced in complex value chains that span across borders. International production and supply chains were criticized because of the economic disruptions they allegedly created when a pandemic interrupted trade and the movement of people across countries, adding to existing fears and concerns about globalization (Kobrin, 2020). Reshaping global supply chains, and possibly making them shorter, more domestic, or more diversified, were therefore proposed to bring some resilience into production networks (Coveri, Cozza, Nascia, \& Zanfei, 2020; Javorcik, 2020; Lin \& Lanng, 2020; O'Leary, 2020; O'Neil, 2020; Shih, 2020). This debate builds on several concepts used in supply chain risk management, starting with 'resilience'1. However, some of the solutions proposed, such as reshoring or diversifying production away from China, may be motivated by a different policy agenda than risk mitigation (Evenett, 2020).
Received: 26 August 2020

Accepted: 17 September 2020

Online publication date: 12 October 2020 


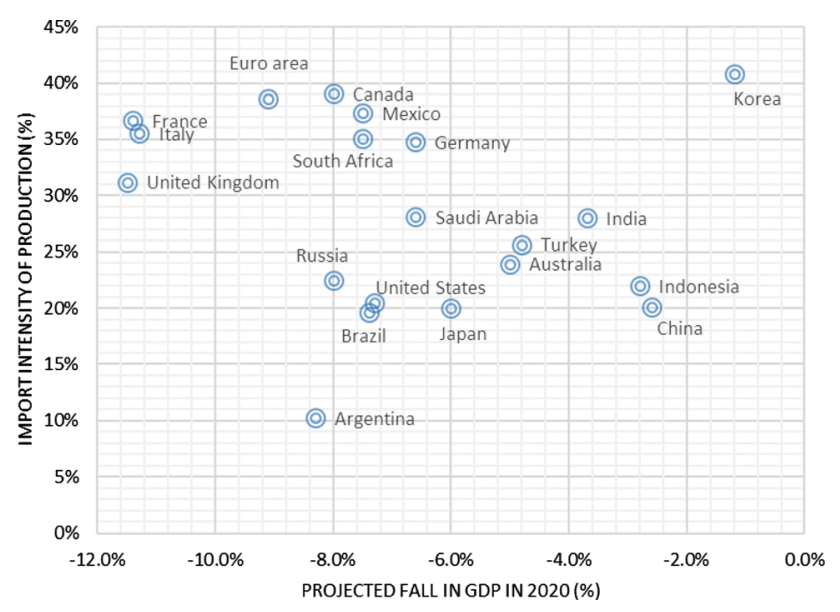

Figure 1 Import intensity of production (2015) and projected fall in GDP in 2020 for G20 economies. Source: OECD Economic Outlook and TiVA database.

In this paper, I argue that before reshaping global supply chains, the debate itself needs to be reframed and more solidly grounded in business reality and in lessons from the literature. There is an important corpus of knowledge in the supply chain and risk management literature that tells firms what to do to improve the resilience of their own production networks. However, there are fewer answers on what resiliency means at the country or global level and what global value chain-oriented policies can be adopted to strengthen it. This is where the international business (IB) and global value chain (GVC) literature can provide further insights. For the IB community, COVID-19 can be seen as an opportunity to bring to policy circles the knowledge on firms and the organization of multinational enterprises (MNEs) that can help to shape the debate on the resilience of supply chains, in line with the ambition of the Journal of International Business Policy (Van Assche, 2018; Van Assche \& Lundan, 2020). As noted by Lorenzen, Mudambi and Schotter (2020), studying MNE risk mitigation strategies in the context of COVID-19 can be a fruitful avenue for IB research. Strange (2020) already provides some interesting thoughts about how GVCs may be reorganized once the crisis is over.

The concept of resilience is not new in the GVC literature. It was used for example to highlight the recovery of trade networks after the Great Financial Crisis in 2008 (Cattaneo, Gereffi, \& Staritz, 2010). More recently, Gereffi (2020) addresses the issue of the resilience of medical supply GVCs. However, as policymakers now seem to associate resilience with a specific type of organization of GVCs where MNEs produce mostly through more localized or shorter supply chains, new questions arise on the type of governance that would allow such organization and on the way policymakers could influence the design of GVCs.

The main risk with the current debate on the economic policy implications of COVID-19 is that it can lead to the use of supply chain concepts by policymakers and international organizations in a way that departs from business reality, thus leading to wrong policy choices. The idea that reshoring unambiguously improves the resilience of supply chains, for example, is not supported by academic research. If there is a case for linking reshoring to higher resiliency, it should be brought up based on evidence, on a deeper discussion of the specific circumstances where it might be a strategy mitigating risks, and one would also need to disentangle the different policy rationales (e.g., bringing jobs back home versus creating more resilient supply chains). What is at stake in this debate are three decades of productivity gains and innovation driven by the internationalization of production, as well as higher levels of income in many emerging economies (World Bank, 2019). Building more resilient supply chains should not lead to the dismantlement of GVCs. It should also not replace the risks related to COVID-19 by new policy hazards and a higher level of uncertainty for companies.

Against this backdrop, the paper suggests that the debate on the policy implications of COVID-19 for international supply chains can be improved in three ways. First, there is a need to better understand the 'vulnerabilities' of global supply chains during COVID-19. That is, the primary step in reshaping the debate is to identify what went wrong during COVID-19. Second, one needs to compare the current policy proposals to established insights from the business literature. I illustrate this with a discussion of the effects of building redundancy in suppliers, just-in-case management, and domestic supply chains. The literature indicates that these strategies are not the best suited to boost resilience in GVCs. Still, their analysis is useful to point to better and more realistic policy options and to see where IB research can help. Lastly, as the literature suggests that it is at the firm level that resilience is built (or at the level of MNEs or lead firms in GVCs), the question is what resilience means at the country or global level and what governments can do to strengthen it. Answering 
these questions can set the stage for a new narrative on the policy implications of COVID-19 for global supply chains.

\section{IDENTIFYING THE PROBLEM BEFORE PRESCRIBING THE SOLUTION}

Unlike the Great Financial Crisis of 2008-2009 that provoked a collapse of trade financing, COVID-19 has prompted an economic crisis that is not specifically a trade crisis. The most affected industries are services that do not rely on long and complex value chains but involve movements of people (Benz, Gonzales, \& Mourougane, 2020). As China was the first country to put a lockdown into effect in January, there was initially the fear that many manufacturing GVCs would be disrupted because key inputs from China would not be delivered. This immediately triggered a series of papers warning about the vulnerabilities of international supply chains and the risk of producing in China (Braw, 2020; Gertz, 2020; Linton \& Vakil, 2020, among others). ${ }^{2}$

Many manufacturing value chains indeed rely on inputs produced in China and calculations with international input-output tables suggest that not having access to Chinese inputs can have a high economic impact on the rest of the world (Baldwin \& Freeman, 2020). However, there is a lack of evidence at this stage of how serious disruptions were related to the (partial) lockdown of the Chinese economy. The reason is that large parts of the world also implemented lockdowns a few weeks later, and demand for most manufacturing goods started to fall at the same time. The Chinese lockdown was also relatively short, and China was the first country to restart its economy. Macro calculations can give an indication of how important a country is as a supplier of inputs for others. However, since companies have risk management strategies and inventories, the actual impact of China temporarily shutting down its exports is not known.

Figure 1 compares the projected fall in GDP in 2020 according to the latest OECD Economic Outlook (OECD, 2020a) with the import intensity of production in G20 economies (an indicator of the reliance on imported inputs all along the value chain). ${ }^{3}$ There is no apparent correlation between the two. The country that is the most dependent on GVCs is Korea, which happens to be the economy with the lowest projected fall in GDP for 2020. At the opposite side of Fig. 1 are EU economies that are dependent on their regional supply chains (but not so much on China) and were severely hit by COVID-19. The idea that dependence on China or some other country creates supply chain vulnerabilities and that COVID-19 has somehow materialized this fear would need to be substantiated by strong quantitative evidence, and this evidence would have to point to the size of economic losses rather than just the existence of disruptions. ${ }^{4}$

When analyzing the evidence, it is also important to propose some counterfactuals. Using a quantitative model of production and trade, Bonadio, Huo, Levchenko and Pandalai-Nayar (2020) find, for example, that there is a high drop in world GDP due to the transmission of the COVID-19 shock through GVCs. However, the drop in GDP is higher under the scenario of a 'renationalization' of global supply chains. Also using a quantitative model, OECD (2020b) highlights that in addition to higher costs, the re-localization of supply chains also leads to higher volatility in output, as there are fewer channels for economic adjustments. Therefore, the right question might not be whether there are vulnerabilities associated with international sourcing but whether these vulnerabilities are higher than if production were concentrated domestically.

While the jury is still out on the actual vulnerabilities of GVCs during COVID-19, there are nonetheless three types of concrete issues that have been highlighted and that deserve to be addressed from a policy perspective. The Chinese supply shock at the end of January and beginning of February 2020 is an example of international supply chain risk. Whether it is a pandemic or a natural disaster, production can suddenly halt in a region of the world and induce a contagion effect to other regions through international supply chains. This was observed in 2011 with the Tohoku earthquake and tsunami in Japan and the Chao Phraya floods in Thailand, or in 2005 with Hurricane Katrina in the United States. Many companies have learned to deal with such country-specific shocks by reinforcing their risk management strategies to mitigate the impact on their production processes. If building more resilient supply chains simply means improving the capacity of firms to face country- or region-specific supply chain risks, there is already abundant literature that indicates how this can be done (Christopher \& Peck, 2004; Sheffi, 2005a; Manuj \& Mentzer, 2008; Pettit, Fiksel, \& Croxton, 2010; Kamalahmadi \& Parast, 2016). From the experience of firms at the beginning of 
2020, it might be possible to revisit this literature and to draw new conclusions from additional case studies, as the field is always evolving (Pettit, Croxton, \& Fiksel, 2019). Such case studies would be particularly useful to give insights on what exactly went wrong with global supply chains beyond the supply and demand shocks that have affected all firms during COVID-19.

The second type of disruption that has triggered the debate on GVCs is those related to the production of medical supplies and more particularly personal protective equipment (PPE). The shortage in face masks, a key product to fight the coronavirus, was also quickly turned into an international supply chain issue. However, the story behind face mask shortages was an exceptional surge in demand (OECD, 2020c; Gereffi, 2020). The country that was concentrating half of the production of face masks in the world (China) also faced a shortage, suggesting that domestic production or not, the way to deal with a surge in demand is not by asking where production takes place but how production capacity can be rapidly ramped up. The shortage was also exacerbated by export restrictions put in place by some countries and by the fierce competition between governments to get access to existing stocks of face masks (Fiorini, Hoekman, \& Yildirim, 2020), highlighting that the problem is not limited to the organization of supply chains. China and GVCs provided the solution to the shortage with massive exports from China to the rest of the world in April-May and one can wonder whether what seemed to be the issue (international sourcing from China) was not retrospectively the solution.

If building more resilient supply chains means preventing future shortages in essential products, the answer might lie in a discussion of stockpiling strategies, contingency plans and public-private partnerships, as well as addressing export restrictions put in place by governments (OECD, 2020c). Like companies, governments need to assess risks and have risk management strategies that include plans for the production of essential goods (Dasaklis, Pappis, \& Rachaniotis, 2012). A closer look at supply chains from an IB perspective could nonetheless bring additional insight on how companies themselves can be prepared for a surge in demand and more generally the volatility in demand (as the surge in demand is followed by a fall when the crisis is finished, leaving many companies with excess production capacity).
The supply chain risk and the issue of volatility in demand are not new and may not require the 'world after' to be radically different from the world of yesterday. Although not necessarily making the headlines when they are unrelated to major natural disasters or a pandemic, disruptions in value chains are frequent (logistics incidents, fire in a warehouse, bankruptcy of a supplier, etc.). Not all companies are well prepared to face risks (McKinsey Global Institute, 2020), but some are (Sheffi, 2015), and building on advances in supply chain and risk management, companies should come up with sensible answers to the question of resilience of their supply chains. New advances in big data analytics and the Internet of things (IoT) are also likely to provide new answers (Birkel \& Hartmann, 2020).

The third type of disruption, and maybe the most prevalent during COVID-19, is those related to the functioning of international trade networks. Trade did not come to a halt at the height of the crisis but it was definitely more complicated (and more costly) for firms to export and to import because of tensions in transport services and issues with border controls (OECD, 2020d; WTO, 2020). With travel bans, the supply of air cargo services was reduced, as half of air cargo shipments are on passenger flights. Longer delays at the border were observed for customs procedures due to new health regulations and tighter controls, also affecting maritime and land transport. New port procedures and rules on the disembarkation of crews were also responsible for reduced capacity in the shipping industry. While transport companies are the ones that can mitigate the impact of such disruptions, it should be noted that they are the consequence of measures put in place by governments and that making border processes faster and safer is the basis of trade facilitation policies. Addressing these types of issues does not require a reorganization of GVCs.

Once the problems faced by firms are clearly identified, it becomes easier to move to an evidence-based policy discussion and to see what type of policies or cooperation across countries could actually bring answers to supply chain risks or volatility in demand.

\section{REDUNDANCY, JUST-IN-CASE MANAGEMENT, AND DOMESTIC SUPPLY}

In addition to not having properly identified the issues to be solved, the debate on COVID-19 and global supply chains has started with strong 
statements about solutions, relying on concepts from the business literature. These concepts tend to be used without actually referring to academic work, which can be explained by the fact that what the literature has to say is quite different from the recommendations made. This can be illustrated with three concepts used in the papers telling us about the new normal of supply chains in the postCOVID-19 world: redundancy, just-in-case inventories, and domestic supply chains.

\section{Redundancy in Suppliers, Inventories, and Production Capacity}

A new word that has appeared in the supply chain vocabulary of policymakers is 'redundancy'. In order to build more robust value chains, there should be some redundancy in suppliers (or supplier diversification) ${ }^{5}$, so that in case of failure of one, others can step in and provide the required inputs. Redundancy is part of the toolkit of risk management strategies and can be applied not only to suppliers but also to inventories or production capacity (Kamalahmadi \& Parast, 2016). However, it is generally regarded as a costly solution to mitigate risk. As summarized by Yossi Sheffi, one of the leading experts in organizational resilience: "Companies can develop resilience in three main ways: increasing redundancy, building flexibility, and changing the corporate culture. The first has limited utility; the others are essential." (Sheffi, 2005b).

In an empirical study looking at 4000 US firms, Jain, Girotra and Netessine (2016) found that supply chains with more diversified sourcing (i.e., the same products are sourced from different suppliers) have slower recovery after a disruption than supply chains relying on single sourcing. One of the reasons for this is that single sourcing is associated with long-term relationships with suppliers. These long-term relationships ensure faster recovery because suppliers are more committed to mitigating risks, are ready to go beyond their contractual obligations to address disruptions, and are more integrated in the production processes of the firm with more information sharing.

Redundancy also means having some extra inventory or additional production capacity to face crises. However, the cost of holding a large inventory or maintaining spare production capacity often outweighs the gains from mitigating risks, particularly in the case of low-probability events. For companies that regularly face hurricanes or adverse climate conditions, for example, redundancy can make sense (Sheffi, 2015), but one cannot expect companies to invest in extra production capacity and inventories for a once-ina-century pandemic.

The issue of redundancy is clearly one where IB research can help to shape the policy debate. The multinational enterprise has been analyzed as a network of subsidiaries operating in different countries with the objective of managing risks, such as exchange rate volatility or policy risk (Kogut \& Kulatilaka, 1994). Even if there are switching costs, COVID-19 has illustrated that some companies used their network to reallocate production, such as Samsung moving temporarily the production of its high-end mobile phones from Korea to Vietnam when its factory was threatened by the coronavirus (Financial Times, 2020). This type of redundancy is more related to flexibility and does not imply duplicating capacity or multiplying the number of suppliers on a permanent basis. However, it is one advantage that MNEs have over companies operating in a single market. Explaining what type of redundancy is useful to build resilience in GVCs and how this redundancy is related to international production could improve the terms of the debate.

\section{Just-in-Time Versus Just-in-Case Strategies}

The discussion on inventories is related to 'just-intime' strategies that have contributed to reducing the size of buffer stocks. Just-in-time (JiT) inventories management was introduced in the 1970s by Toyota and was quickly adopted by many manufacturing companies in the world as an effective strategy to reduce costs, shorten lead times, and improve the quality of production (Keller \& Kazazi, 1993). JiT is part of lean manufacturing strategies aimed at reducing all costs and waste in the production process (Bhamu \& Singh Sangwan, 2014). Now the idea would be to switch to justin-case' management where a loss in economic efficiency would be traded-off for increased security in supply of inputs. But what exactly is the underlying management strategy? 'Just-in-case' is an expression used in the literature to describe what was before JiT or in the risk management literature to discuss whether higher inventories are needed (Srinidhi \& Tayi, 2004). But it is not a specific type of management model that could be mainstreamed to make supply chains more resilient, unless the idea is to come back to the management of inventories as it was before the ICT revolution and modern logistics. 'Just in case' is a very vague proposal that maybe only suggests 
adjusting JiT to better take into account risk management.

However, this is already the case, as risk management strategies and JiT generally go together. Firms that invest in reducing inventories and making their production process as efficient as possible all along the value chain are also the ones investing in the monitoring and management of risks. This can be illustrated with Cisco's supply chain risk management that is often mentioned as an example of best practices. Cisco aims at identifying the right level of inventories to achieve both resilience and efficiency (Miklovic \& Witty, 2010). In May, in the middle of the COVID-19 crisis, 3M - one of the main manufacturers of face masks - announced that it plans to reduce the cost of its inventories by USD 500 million in the coming years in order to operate its supply chains more efficiently (Supply Management, 2020). This highlights that companies producing essential goods are also looking for lean inventories and do not see it as a contradiction with their risk management and business continuity objectives.

A point made by Pisch (2020) is also that JiT companies have lower costs for inventories. Therefore, if there is a need to increase inventories to reduce risks, they are also better placed to do it in a more competitive way. A related consideration is that when there is a fall in demand, like in the current COVID-19 crisis, companies with low inventories have smaller losses than those with high inventories. The paradox is that if 'just-incase' was currently the predominant strategy of firms, more of them could become bankrupt with COVID-19.

Finally, it should be noted that the manufacturing paradigm has also recently shifted from 'lean manufacturing' to 'agile manufacturing' (Potdar, Routroy, \& Behera, 2017). While some firms may still follow JiT and lean production, new business models put more emphasis on the capacity of firms to adapt to change and to produce in uncertain environments. Some IB scholars suggest that the international business environment is now characterized by volatility, uncertainty, complexity, and ambiguity (VUCA) and that, in this new VUCA world, firms need to develop dynamic capabilities to remain competitive (Bennett \& Lemoine, 2014; Teece, 2014; Van Tulder, Verbeke, \& Jankowska, 2019). What authors reacting to COVID-19 are calling for is already something under way (and where efficiency does not have to be sacrificed to achieve resilience). Further insights on the new paradigms of firms and what they do and intend to do as a consequence of the COVID-19 pandemic could also help to bring the policy debate closer to the decisions of firms.

\section{Safer at Home? Domestic Production and Risks}

The idea that domestic production is more resilient than international production is also not something found in the risk management literature. ${ }^{6}$ The main reason for this is that there are many risks in the domestic economy as well and this literature does not try to identify where is the safest place to produce but what strategies can companies put in place to mitigate risks. For example, companies producing in Japan will always face a high risk of earthquakes. Some countries may be less exposed to natural disasters but will face other risks such as exchange rate volatility, strikes, social unrest, or a pandemic. There are also risks that are not related to the location of production, such as bankruptcy. If a supplier goes bankrupt (which is a high risk during the COVID-19 recession), it does not matter whether it produces in the domestic economy or not. Inputs will no longer be supplied. Another type of risk that has recently gained attention is cyber risk (Ghadge, Weiß, Caldwell, \& Wilding, 2019). As supply chains increasingly rely on information and communication technologies, they are more vulnerable than before to cyber-attacks and IT failures, a risk that is not lower when production is domestic (and potentially higher if domestic firms all use the same IT infrastructure).

Risk management is about looking at the whole portfolio of risks, which can lead to different decisions in terms of the location of production. Domestic production might indeed be the strategy in some cases, but it would be the result of a decision integrating a variety of risks - and risk is only one determinant of the location of production among others.

Until recently, the concept of reshoring could not be found in the business literature and was mentioned more as a hypothetical case when discussing offshoring. Some anecdotal evidence on companies actually reshoring their activities has prompted new research. However, the literature does not regard supply chain risk as one of the main determinants of reshoring (Wiesmann, Snoei, Hilletofth, \& Eriksson, 2017). Minimizing disruptions in supply chains and reducing delivery times might be a driver but studies generally emphasize the limits of reshoring (Bailey \& De Propris, 2014). Some further insights that could be brought from 
the IB literature are what firms have to lose (or to change) when being disconnected from the most efficient suppliers or from international knowledge networks. There are advantages in producing locally, such as not supporting all the additional costs related to cross-border transactions and managing activities abroad. The question is what kind of location advantages from offshored places are traded for these domestic location advantages.

More generally, there are important insights from the IB literature that can help policymakers to develop a better understanding of the relationship between the organization of global supply chains and risk. Risk is part of the location advantages in Dunning's eclectic theory (Dunning, 1980). The policy or institutional risk in the host country of MNEs has always been regarded as an important determinant of FDI, with heterogeneous responses (Buckley, Chen, Clegg, \& Voss, 2018). Volatility in real exchange rates is another risk specific to international production that can lead firms to look for options and the flexibility of switching production across countries (Kogut \& Kulatilaka, 1994). Real options theory provides a theoretical basis for this type of diversification strategy and can be applied to a variety of other risks beyond exchange rates (Chi, Trigeorgis, \& Tsekrekos 2019). Internalization theory can also potentially address the issue of risks in supply chains with an answer not limited to the geographical location of activities but also the boundaries of firms and what they decide to outsource or not (Strange, 2020).

The geography of MNEs is the result of complex strategic decisions (Mudambi et al., 2018). A new imperative related to the mitigation of supply chain risks can affect these decisions and change the geography and boundaries of firms, but the idea of reshoring seems simplistic as compared to the sophisticated location decisions described in the IB literature and the constraints faced by firms to remain competitive.

\section{GOVERNMENTS WANT TO ACT BUT NEED HELP TO KNOW WHAT TO DO}

Now that it seems accepted that COVID-19 has revealed the vulnerabilities of international supply chains, governments are under pressure to show that they are taking some action to fix GVCs. This is why it is dangerous to leave an analytical vacuum where the solutions proposed would only be the ones analyzed in the previous section. Reshaping the debate and introducing a different set of answers derived from the business literature and supported by empirical evidence requires addressing three questions. One is a matter of communication, and the two others are more fundamental.

While there is some convergence in the risk management literature on what can improve the resilience of supply chains, the first question is how to communicate the results of this research to policymakers. One issue is the diversity in the concepts used to describe what firms need to achieve. Under the list of 'capabilities' to be developed are the concepts of flexibility, agility, visibility, adaptability, and collaboration (Kamalahmadi \& Parast, 2016). Each concept casts light on a different aspect of what makes firms able to quickly react to a crisis and mitigate its impact, but there is also some overlap between them. As concepts, they also carry some level of abstraction and both businesses and policymakers might regard them as a bit disconnected from their daily work. It would be useful to simplify the message and to synthesize these different aspects. One reason why the concept of 'resilience' is successful (while not always properly used) is that it sounds like a reasonable and simple objective. As the pendulum seems to be right now more on the side of limiting international supply, increasing inventories and diversifying suppliers, there is a need to move it more in the direction of flexibility and agility where firms do not have to become less efficient to mitigate risks. The role of collaboration (Scholten \& Schilder, 2015), which is related to visibility, might also be interesting to emphasize from a policy perspective (having in mind governments as potential actors in this collaboration).

The second question is whether solutions are at the firm level or the GVC level. The risk management literature focuses on making firms resilient, and this can be measured by the time they take to recover from a disruption. According to Martins de Sá et al. (2020), resilience in the value chain does not depend on the organizational features of the supply chain but rather on efficient risk management strategies in firms that are able to reconfigure the value chain to mitigate the disruptions.

Here it might be useful to refer to GVC analysis and to the different models of governance of supply chains (Gereffi, Humphrey, \& Sturgeon, 2005). If a lead firm controls the whole value chain (captive value chain or vertically integrated value chain), ensuring that the lead firm has the capabilities needed for effective risk mitigation might be enough to create resilience all along the supply 
chain. It might also be the case in some relational value chains where the same is achieved through collaboration. In the case of market linkages and modular value chains, one may have to distinguish the resilience of the supply chain from the resilience of specific firms. Moving from policy proposals focusing mainly on the design of supply chains (e.g., to make them shorter, more domestic, and more diversified) to proposals enhancing the capabilities of firms (e.g., to help them to develop flexibility and agility, as well as visibility in their supply chains) requires clarifying the intersection between firms and GVCs (Pananond, Gereffi and Pedersen, 2020).

On the one hand, the concept of resilience at the GVC level (the way policymakers understand it, i.e., value chains for a large range of final producers belonging to the same broad industry, such as medical supplies or food) is more difficult to define, as different firms will recover at a different pace after a disruption (and not all of them might be affected in the first place). In theory, the production of final goods can only resume when production all along the value chain starts again, but it can still leave some final producers and input suppliers at different stages of recovery when considering GVCs of a whole industry.

On the other hand, the type of resilience that is discussed by policymakers (and which is more about reducing and diversifying risks rather than shortening the time to recover from a disruption) might be easier to achieve at the GVC level. For example, reducing the dependence on inputs from a specific partner country can be the result of different firms sourcing from different countries while not asking each firm to diversify suppliers (Ferrarini \& Hummels, 2014).

The third question is how governments can influence sourcing decisions or capabilities of firms, as well as the organization of GVCs. It should be noted that this question is the same whether one is promoting reshoring or agility. It is a traditional question in the literature in relation to the design of GVC-oriented industrial policy (Gereffi \& Sturgeon, 2013), the public/private governance of value chains (Bair, 2017), the role of the state in GVCs (Horner \& Alford, 2019), as well as the impact of investment and trade regimes on decisions of MNEs (Buckley, 2018; Rugman \& Verbeke, 2017). It may receive different answers based on whether governments want to encourage or constrain firms in adopting specific strategies.
Leaving aside the option where governments themselves become actors in GVCs (through government ownership), constraints (e.g., tariffs, taxes) or incentives to firms (e.g., subsidies, tax breaks) inevitably lead to economic distortions. It would be a paradox to resort to such mechanisms when the origin of current trade tensions and policy uncertainties for investment lies in market-distorting government support and when several countries highlight the need for levelling the playing field (OECD, 2019). Some governments might still follow this path, but a more coherent policy framework that would not suggest increasing policy risks and costs for companies in order to build resilience would have to rely on a two-pronged approach.

First, as highlighted before, there are a series of policies, such as trade facilitation or the regulation of transport and infrastructure services, where the government is directly in charge of setting the rules and can create the conditions for firms to mitigate risks and increase their agility (e.g., by eliminating red tape, creating emergency certification procedures, etc.). The reduction of policy uncertainties, including at the global level, is also in the hands of governments, although more dependent on the success of international cooperation (which is not warranted in the current geopolitical environment).

Second, some dialogue with the private sector and possibly the organization of public-private platforms at the level of GVCs (Hoekman, 2014) can allow governments to encourage firms to put more emphasis on the issue of resilience, while not introducing financial constraints or incentives. Different types of incentives can be provided, such as with the organization of 'stress tests' that would put companies in the position of proving that they have taken the necessary steps to be resilient, particularly in the context of the production of essential goods (Simchi-Levi \& Simchi-Levi, 2020). Such stress tests could also provide information to governments to organize their own risk management strategies (e.g., the right level of national stockpiling to meet a surge in demand beyond the capacity of firms to ramp up their production) and to improve their policies (e.g., information on policy-related costs encountered by firms in their operations). A GVC-level dialogue would also allow firms to cooperate among themselves to be better prepared for risks.

The basis for developing and promoting such policy proposals would be a new narrative with the following elements: 
(1) COVID-19 has confirmed interdependencies between economies. There are risks inherent to these interdependencies but they are also the source of growth and development. At this stage, there is no reason to believe that reducing interdependencies would reduce the exposure of economies to risks. On the contrary, simulations suggest that not only the income of countries would be lower but also more volatile.

(2) There are concrete issues that can be addressed by policymakers at the GVC level for economies to be better prepared for risks in the future. These issues do not require a new paradigm for GVCs but may involve their restructuring in a process driven by companies and tailored to the specific conditions they operate in. Three of them were discussed in the first section of the paper: international supply chain risks and contagion effects, surges in demand for essential goods, and disruptions in trade and transport networks. In these three areas, a GVC perspective makes sense and a combination of actions by firms and governments can mitigate the impact of the next crises.

(3) There is no trade-off between efficiency and lower risk. There are trade-offs between different types of risks and firms have to balance the costs and benefits of risk management. However, the most efficient firms are also the ones that are the best at mitigating risks (Sheffi, 2015). Promoting agility and flexibility is an agenda that can serve both the objective of resilience and economic recovery after COVID19.

(4) The location of production is a complex issue where risk is one determinant among others. There is no rationale for suggesting a specific organization of GVCs that would create resilience, but one type of risk that governments can control is policy risk. They can diminish uncertainties within their domestic economy and rely on international cooperation to reduce international policy risks and trade tensions.

\section{CONCLUSION}

In its 2020 World Investment Report, UNCTAD (2020) is already predicting that reshoring, diversification, and regionalization will drive the restructuring of GVCs in the coming years. It might be premature, as these strategies have been proposed in columns or opinion pieces and are not grounded in business experience, research, and analytical work. Calls for more resilient supply chains have been heard before, after 2001 when the emphasis was on risks related to terrorism or after 2011 when the emphasis was on natural disasters. Businesses that nowadays are described to be focused too much on efficiency and insufficiently prepared for risks related to hyper-globalization have already been through many crises that have prompted them to act. Still, COVID-19 is an unprecedented crisis, and its global scale might lead more companies to rethink their strategies and to put more emphasis on risk management. Companies that have been through this process in the past have not resorted to reshoring or regionalization and have not significantly diversified their supply chains. What could be different this time is that firms also have to adjust to deep changes in their environment, such as the digital transformation, climate change, or rising protectionism and trade tensions. Therefore, we will see some structural shifts in the organization of global supply chains and COVID-19 might be an accelerator of these shifts in some cases. It is too early, however, to predict what solutions will lead businesses to thrive in this uncertain environment.

Still, it is useful to have the current debate on the policy implications of COVID-19 for global supply chains. First, this debate can prevent governments from making the wrong policy choices in the future. That is, there is an opportunity for researchers to convey to policymakers relevant knowledge that will improve their policies or prevent them from making mistakes. Second, the overlap between the debate on the resilience of supply chains and the debate on protectionism and economic nationalism can also offer new ways of addressing concerns about globalization. While building more resilient GVCs could be used as a pretext for protectionist policies, it is a two-edged sword. Demonstrating that domestic value chains are increasing certain types of risks or that international sourcing can improve the access to essential goods would not only reduce the appeal of protectionist policies but do it on different grounds than just pointing at a welfare loss. Third, new research on global supply chains and risk mitigation during COVID-19 could provide novel insights, as well as new policy recommendations. Different questions could also be examined, not being constrained by the initial emphasis on reshoring and redundancy. For example, the reshoring debate focuses on resilient value chains for developed countries and 
does not take into account developing and emerging economies. These countries would not only lose some economic activity if reshoring was the new normal, but would also face a more difficult access to essential goods when they are produced by MNEs from developed countries.

\section{ACKNOWLEDGEMENTS}

The author is writing in a strictly personal capacity. The views expressed do not reflect those of the OECD Secretariat or the member countries of the OECD. The author is grateful to the editor, Ari Van Assche, and to two anonymous referees for their many helpful comments and suggestions.

\section{NOTES}

${ }^{1}$ In the risk management literature, resilience is defined as "the ability of a system to return to its original state or move to a new more desirable state after being disturbed" (Christopher \& Peck, 2004). In the supply chain, resilience is about reducing the time it takes for companies to resume normal production once a disruption has occurred. It is different from 'robustness', which is the ability of supply chains to maintain their function despite internal or external disruptions (Brandon-Jones, Squire, Autry, \& Petersen, 2014). Authors who ask for more resilient supply chains in the context of COVID-19 are often mistaking resilience for robustness. They focus on the description of the disruptions but do not report how quickly international supply chains have generally adjusted, which is the sign of their resilience. On the policy implications of robustness versus resilience in GVCs, see Miroudot (2020).

${ }^{2}$ The debate on China overlaps with another type of risk that is not related to COVID-19 but to trade tensions between the United States and China. There is evidence that an increasing number of companies are moving their production out of China to avoid trade barriers imposed on Chinese exports or potential political pressures (Baker McKenzie, 2020). The fact that reshoring and

\section{REFERENCES}

Baker McKenzie. 2020. Supply chains reimagined: Recovery and renewal in Asia Pacific and beyond. https://www. bakermckenzie.com/en/insight/publications/2020/08/supplychains-reimagined. Accessed August 20. domestic production are suggested to build more resilient supply chains is likely to be linked to economic nationalism and the anti-globalization sentiment. The issue of concentration of production, which is relevant for supply chain disruptions, is also generally analyzed only in relation to China.

${ }^{3}$ See Timmer et al. (2016) for the calculation of the import intensity of production. The ratio indicates for each dollar of output the value of all intermediate inputs traded upstream in the value chain. It was calculated for 2015 (latest year available) with data from the OECD Trade in Value Added (TiVA) database. Data for the EU are based on the Euro area only.

${ }^{4}$ Business surveys generally indicate high rates of disruptions but without an indication of the consequences of these disruptions (e.g., whether firms have stopped producing or not). See for example the surveys conducted by the Institute for Supply Management (www.instituteforsupply management.org), the data collected on firmlevelrisk.com and McKinsey Global Institute (2020).

${ }^{5}$ The expression 'supplier diversification' is only partially a synonym for redundancy. Redundancy suggests that there are (at least) two suppliers for the same input (in different locations). Supplier diversification can also be understood as diversifying the sources of supply by working with different suppliers in different countries but each of them providing different inputs (i.e., maintaining single sourcing). It can spread the supply chain risk but does not offer the same level of business continuity when one of these suppliers fails to provide the inputs.

${ }^{6}$ The argument is also about shorter supply chains, which can be understood as a regionalization of production and not just relying on domestic suppliers. The relationship between distance and risk is linked to regional integration and economic cooperation among countries, which can reduce the policy and institutional risk. Cultural factors could also play a role with lower transaction costs and easier co-operation between firms when there is some cultural proximity. See e.g., Shenkar (2012) for a discussion of cultural distance.

Bailey, D., \& De Propris, L. 2014. Manufacturing reshoring and its limits: The UK automotive case. Cambridge Journal of Regions, Economy and Society, 7(3): 379-395. https://doi.org/ $10.1093 /$ cjres/rsu019. 
Bair, J. 2017. Contextualising compliance: Hybrid governance in global value chains. New Political Economy, 22(2): 169-185. https://doi.org/10.1080/13563467.2016.1273340.

Baldwin, R., \& Freeman, R. 2020. Supply chain contagion waves: Thinking ahead on manufacturing 'contagion and reinfection' from the COVID concussion. VoxEU. https:// voxeu.org/article/covid-concussion-and-supply-chaincontagion-waves. Accessed August 14.

Bennett, N., \& Lemoine, G. J. 2014. What a difference a word makes: Understanding threats to performance in a VUCAworld. Business Horizons, 57(3): 311-317.

Benz, S., Gonzales, F., \& Mourougane, A. 2020. The impact of COVID-19 international travel restrictions on services-trade costs: Some illustrative scenarios. Covid Economics, 45: 65-76.

Bhamu, J., \& Singh Sangwan, K. 2014. Lean manufacturing: Literature review and research issues. International Journal of Operations \& Production Management, 34(7): 876-940. https://doi.org/10.1108/IJOPM-08-2012-0315.

Birkel, H. S., \& Hartmann, E. 2020. Internet of Things - The future of managing supply chain risks. Supply Chain Management, 25(5): 535-548. https://doi.org/10.1108/SCM-092019-0356.

Bonadio, B., Huo, Z., Levchenko, A., \& Pandalai-Nayar, N. 2020. Global supply chains in the pandemic. NBER Working Paper No. 27224.

Brandon-Jones, E., Squire, B., Autry, C. W., \& Petersen, K. J. 2014. A contingent resource-based perspective of supply chain resilience and robustness. Journal of Supply Chain Management, 50(3): 55-73. https://doi.org/10.1111/jscm. 12050.

Braw, E. 2020. Blindsided on the supply side. Foreign Policy, March 4. https://foreignpolicy.com/2020/03/04/blindsidedon-the-supply-side/. Accessed August 16.

Buckley, P. J. 2018. Towards a theoretically-based global foreign direct investment policy regime. Journal of International Business Policy, 1(3-4): 184-207. https://doi.org/10.1057/ s42214-018-0011-2.

Buckley, P. J., Chen, L., Clegg, L. J., \& Voss, H. 2018. Risk propensity in the foreign direct investment location decision of emerging multinationals. Journal of International Business Studies, 49(2): 153-171. https://doi.org/10.1057/s41267017-0126-4.

Cattaneo, O., Gereffi, G., \& Staritz, C. 2010. Global value chains in a post-crisis world: A development perspective. Washington, DC: World Bank.

Chi, T., Li, J., Trigeorgis, L. G., \& Tsekrekos, A. E. 2019. Real options theory in international business. Journal of International Business Studies, 50(4): 525-553. https://doi.org/10. 1057/s41267-019-00222-y

Christopher, M., \& Peck, H. 2004. Building the resilient supply chain. International Journal of Logistics Management, 15(2): 114. https://doi.org/10.1108/09574090410700275.

Coveri, A., Cozza, C., Nascia, L., \& Zanfei, A. 2020. Supply chain contagion and the role of industrial policy. Journal of Industrial and Business Economics, 47(3): 467-482. https://doi.org/10. 1007/s40812-020-00167-6.

Dasaklis, T. K., Pappis, C. P., \& Rachaniotis, N. P. 2012. Epidemics control and logistics operations: A review. International Journal of Production Economics, 139(2): 393-410. https://doi.org/10.1016/j.ijpe.2012.05.023.

Dunning, J. H. 1980. Toward an eclectic theory of international production: Some empirical tests. Journal of International Business Studies, 11(1): 9-31. https://doi.org/10.1057/ palgrave.jibs.8490593.

Evenett, S. 2020. Chinese whispers: COVID-19, supply chains in essential goods, and public policy. Journal of International Business Policy, forthcoming.

Ferrarini, B., \& Hummels, D. 2014. Asia and global production networks: Implications for trade, incomes and economic vulnerability. In B. Ferrarini \& D. Hummels (Eds), Asia and global production networks: 1-15. Cheltenham: ADB and Edward Elgar.

Fiorini, M., Hoekman, B., \& Yildirim, A. 2020. COVID-19: Expanding access to essential supplies in a value chain world. In R. Baldwin \& S. I. Evenett (Eds), COVID-19 and trade policy: Why turning inward won't work: 63-76. London: CEPR Press.

Financial Times. 2020. Inside Samsung's fight to keep its global supply chain running. May 8 .

Gereffi, G. 2020. What does the COVID-19 pandemic teach us about global value chains? The case of medical supplies. Journal of International Business Policy, 3(3): 287-301. https:// doi.org/10.1057/s42214-020-00062-w.

Gereffi, G., Humphrey, J., \& Sturgeon, T. 2005. The governance of global value chains. Review of International Political Economy, 12(1): 78-104. https://doi.org/10.1080/09692290500049 805 .

Gereffi, G., \& Sturgeon, T. 2013. Global value chain-oriented industrial policy: The role of emerging economies. In D. Elms \& P. Low (Eds), Global value chains in a changing world: 329 360. Geneva: World Trade Organization.

Gertz, G. The coronavirus will reveal hidden vulnerabilities in complex global supply chains. Brookings, March 5. https:// www.brookings.edu/blog/future-development/2020/03/05/ the-coronavirus-will-reveal-hidden-vulnerabilities-in-complexglobal-supply-chains/. Accessed August 16.

Ghadge, A., Weiß, M., Caldwell, N. D., \& Wilding, R. 2019. Managing cyber risk in supply chains: A review and research agenda. Supply Chain Management, 25(2): 223-240. https:// doi.org/10.1108/SCM-10-2018-0357.

Hoekman, B. 2014. Supply chains, mega-regionals and multilateralism: A roadmap for the WTO. London: CEPR Press.

Horner, R., \& Alford, M. 2019. The roles of the state in global value chains. In S. Ponte, G. Gereffi \& G. Raj-Reichert (Eds), Handbook on global value chains: 555-569. Cheltenham, UK: Edward Elgar.

lain, N., Girotra, K., \& Netessine, N. 2016. Recovering from supply interruptions: The role of sourcing strategies. INSEAD Working Paper No. 2016/58/TOM.

Javorcik, B. 2020. Global supply chains will not be the same in the post-COVID-19 world. In R. Baldwin \& S. J. Evenett (Eds), COVID-19 and trade policy: Why turning inward won't work: 111-116. London: CEPR Press.

Kamalahmadi, M. \& Parast, M. M. 2016. A review of the literature on the principles of enterprise and supply chain resilience: Major findings and directions for future research. International Journal of Production Economics, 171(Part 1): 116133. https://doi.org/10.1016/j.ijpe.2015.10.023.

Keller, A. Z., \& Kazazi, A. 1993. 'Just-in-time' manufacturing systems: A literature review, Industrial Management \& Data Systems, 93(7): 2-32. https://doi.org/10.1108/ 02635579310044254.

Kobrin, S. J. 2020. How globalization became a thing that goes bump in the night. Journal of International Business Policy, 3(3): 280-286. https://doi.org/10.1057/s42214-020-00060-y.

Kogut, B., \& Kulatilaka, N. 1994. Operating flexibility, global manufacturing, and the option value of a multinational network. Management Science, 40(1): 123-139. https://doi. org $/ 10.1287 / \mathrm{mnsc} .40 .1 .123$.

Lin, J., \& Lanng, C. 2020. Here's how global supply chains will change after COVID-19. World Economic Forum. https:// www.weforum.org/agenda/2020/05/this-is-what-globalsupply-chains-will-look-like-after-covid-19/. Accessed August 16.

Linton, T., \& Vakil, B. 2020. Coronavirus is proving we need more resilient supply chains. Harvard Business Review, 5 March. https://hbr.org/2020/03/coronavirus-is-proving-that-weneed-more-resilient-supply-chains. Accessed August 16.

Lorenzen, M., Mudambi, R., \& Schotter, A. 2020. International connectedness and local disconnectedness: MNE strategy, city-regions and disruption. Journal of International Business Studies, https://doi.org/10.1057/s41267-020-00339-5. 
Manuj, I., \& Mentzer, J. T. 2008. Global supply chain risk management. Journal of Business Logistics, 29(1): 133-156. https://doi.org/10.1002/j.2158-1592.2008.tb00072.x.

Martins de Sá, M., Laczynski de Souza Miguel, P., Peregrino de Brito, R., \& Farias Pereira, S. C. 2020. Supply chain resilience: The whole is not the sum of the parts. International Journal of Operations \& Production Management, 40(1): 92-115. https:// doi.org/10.1108/IJOPM-09-2017-0510.

McKinsey Global Institute. 2020. Risk, resilience, and rebalancing in global value chains. https://www.mckinsey.com/ business-functions/operations/our-insights/risk-resilience-andrebalancing-in-global-value-chains. Accessed August 12.

Miklovic, D., \& Witty, R. J. 2010. Case study: Cisco addresses supply chain risk management. Gartner Industry Research.

Miroudot, S. 2020. Resilience versus robustness in global value chains: Some policy implications. In R. Baldwin \& S. J. Evenett (Eds), COVID-19 and trade policy: Why turning inward won't work: 117-130. London: CEPR Press.

Mudambi, R., Li, L., Ma, X., Makino, S., Qian, G., \& Boschma, R. 2018. Zoom in, zoom out: Geographic scale and multinational activity. Journal of International Business Studies, 49(8): 929941. https://doi.org/10.1057/s41267-018-0158-4.

O'Leary, L. 2020. The modern supply chain is snapping. The Atlantic, March 26. https://www.theatlantic.com/ideas/ archive/2020/03/supply-chains-and-coronavirus/608329/. Accessed August 17.

O'Neil, S. K. 2020. How to pandemic-proof globalization: Redundancy, not re-shoring, is the key to supply chain security. Foreign Affairs, April 1. https://www.foreignaffairs. com/articles/2020-04-01/how-pandemic-proofglobalization. Accessed August 17.

OECD. 2020a. OECD Economic Outlook 2020, Vol 1. OECD Publishing. http://www.oecd.org/economic-outlook/june2020/\#Report. Accessed July 28.

OECD. 2020b. Shocks, risks and global value chains: Insights from the OECD METRO model, June 29. Paris: OECD.

OECD. 2020c. The face mask global value chain in the COVID19 outbreak: Evidence and policy lessons, May 4. Paris: OECD.

OECD. 2020d. Trade facilitation and the COVID-19 pandemic, 22 April. Paris: OECD.

OECD. 2019. Levelling the playing field, February. Paris: OECD.

Pananond, P., Gereffi, G., \& Pedersen, T. 2020. An integrative typology of global strategy and global value chains: The management and organization of cross-border activities. Global Strategy Journal, 10(3): 421-443. https://doi.org/10. 1002/gsj.1388.

Pettit, T. J., Croxton, K. L., \& Fiksel, J. 2019. The evolution of resilience in supply chain management: A Retrospective on Ensuring Supply Chain Resilience Journal of Business Logistics, 40(1): 56-65. https://doi.org/10.1111/jbl.12202.

Pettit, T. J., Fiksel, J., \& Croxton, K. L. 2010. Ensuring supply chain resilience: Development of a conceptual framework. Journal of Business Logistics, 31(1): 1-21. https://doi.org/10. 1002/j.2158-1592.2010.tb00125.x.

Pisch, F. 2020. Managing global production: Theory and evidence from just-in-time supply chains. CEP Discussion Paper No. 1689.

Potdar, P. K., Routroy, S., \& Behera, A. 2017. Agile manufacturing: A systematic review of literature and implications for future research. Benchmarking: An International Journal, 24(7): 2022-2048. https://doi.org/10.1108/BIJ-06-2016-0100.

Rugman, A. M., \& Verbeke, A. 2017. Global corporate strategy and trade policy. London: Routledge.

Sheffi, Y. 2005a. The resilient enterprise: Overcoming vulnerability for competitive advantage. Cambridge, MA: MIT Press.

Sheffi, Y. 2005b. Building a resilient supply chain. Harvard Business Review supply chain strategy, 1(8): 1-2.

Sheffi, Y. 2015. The power of resilience. How the best companies manage the unexpected. Cambridge, MA: MIT Press.

Shenkar, O. 2012. Cultural distance revisited: Towards a more rigorous conceptualization and measurement of cultural differences. Journal of International Business Studies, 43(1): 111. https://doi.org/10.1057/jibs.2011.40

Shih, W. 2020. Is it time to rethink globalized supply chains? Sloan Management Review, Summer 2020. https:// sloanreview.mit.edu/article/is-it-time-to-rethink-globalizedsupply-chains/. Accessed August 17.

Sholten, K., \& Schilder, S. 2015. Collaboration in supply chain resilience. Supply Chain Management, 20(4): 471-484. https:// doi.org/10.1108/SCM-11-2014-0386.

Simchi-Levi, D., \& Simchi-Levi, E. 2020. We need a stress test for critical supply chains. Harvard Business Review, 28 April. https://hbr.org/2020/04/we-need-a-stress-test-for-criticalsupply-chains. Accessed June 2.

Srinidhi, B., \& Tayi, G. K. 2004. Just in time or just in case? An explanatory model with informational and incentive effects. Journal of Manufacturing Technology Management, 15(7): 567574. https://doi.org/10.1108/17410380410555817.

Strange, R. 2020. The 2020 Covid-19 pandemic and global value chains. Journal of Industrial and Business Economics, 47(3): 455-465. https://doi.org/10.1007/s40812-020-00162-

Supply Management. 2020. 3M cuts inventory by $\$ 370 \mathrm{~m}$. May 4. https://www.cips.org/supply-management/news/2020/ may/3m-cuts-inventory-by-370m/. Accessed August 20.

Teece, D. 2014. A dynamic capabilities-based entrepreneurial theory of the multinational enterprise. Journal of International Business Studies, 45(1): 8-37. https://doi.org/10.1057/jibs. 2013.54

Timmer, M. P., Los, B., Stehrer, R., \& de Vries, G. J. 2016. An anatomy of the global trade slowdown based on the WIOD 2016 release. GGDC Research Memorandum GD-162.

UNCTAD. 2020. World Investment Report, 2020 - International production beyond the pandemic. Geneva: UNCTAD.

Van Assche, A. 2018. From the editor: Steering a policy turn in international business - Opportunities and challenges. Journal of International Business Policy, 1(3-4): 117-127. https://doi. org/10.1057/s42214-018-0013-0.

Van Assche, A., \& Lundan, S. 2020. From the editor: COVID-19 and international business policy. Journal of International Business Policy, 3(3): 273-279. https://doi.org/10.1057/ s42214-020-00065-7.

Van Tulder, R., Verbeke, A., \& Jankowska, B. (Eds). 2019. International business in a VUCA world: The changing role of states and firms. Bingley: Emerald Publishing Limited.

Wiesmann, B., Snoei, J. R., Hilletofth, P., \& Eriksson, D. 2017. Drivers and barriers to reshoring: A literature review on offshoring in reverse. European Business Review, 29(1): 1542. https://doi.org/10.1108/EBR-03-2016-0050.

World Bank. 2019. World Development Report 2020 - Global value chains: Trading for development. Washington, DC: World Bank.

WTO. 2020. Trade in services in the context of COVID-19. Information note. https://www.wto.org/english/tratop_e/ covid19_e/services_report_e.pdf. Accessed September 10.

\section{ABOUT THE AUTHOR}

Sébastien Miroudot is Senior Trade Policy Analyst in the Trade in Services Division of the OECD Trade and Agriculture Directorate. He was previously a research assistant at Groupe d'Economie Mondiale and taught in the master's degree programme at SciencesPo, Paris. During 2016-2017, he was visiting professor at the Graduate School of International Studies of Seoul National University. At the OECD, his current work is on the measurement of 
trade in value-added terms, the relationship between trade and investment, and the trade policy implications of global value chains. He holds a PhD in international economics from SciencesPo.

Publisher's Note Springer Nature remains neutral with regard to jurisdictional claims in published maps and institutional affiliations.

Accepted by Ari Van Assche, Deputy Editor, 17 September 2020. This paper is part of a series of contributions dealing with the implications of the COVID-19 pandemic on international business policy, and it was single-blind reviewed. 